MARIA MANUELA MENDES

CEIS-IUL, ISCTE - Instituto Universitário de Lisboa and CIAUD,

Faculdade de Arquitetura, Universidade de Lisboa

OLGA MAGANO

Open University, Portugal (UAb) and CEIS-IUL, ISCTE - Instituto

Universitário de Lisboa

ANA RITA COSTA

CRIA-IUL, ISCTE - Instituto Universitário de Lisboa

\title{
Public policies and social change: The case of the success and continuity of schooling paths of Ciganos
}

\section{ABSTRACT}

The consolidation of the welfare state that took place after the 1974 revolution, particularly in the 1980s, improved the living standards of Portuguese citizens. The improvements were directly reflected in Portuguese Cigano families and individuals, although the great majority remain at high risk of poverty. In 2011 the European Council proposed the definition of national strategies for integration of Ciganos, opening the door for achieving better living conditions of European Roma citizens. The national strategies focus on four fundamental domains: education, employment, healthcare and housing. At the present time, Portugal is implementing its National Strategy for the Integration of Cigano Communities. In terms of education, compared

\section{KEYWORDS}

Cigano

public policies education schooling paths. educational continuity social inequalities 
1. The research project ran from June 2013 to May 2015, supported by the Foundation for Science and Technology (FCT), reference PTDC/IVC$\mathrm{PEC} / 4909 / 2012$ and was developed in partnership between the Centro de Estudos das Migrações e das Relações Interculturais (CEMRI) and CIES, ISCTE - Instituto Universitário de Lisboa.

2.. In Portugal, mandatory schooling is composed of three primary level school cycles (the first cycle - from grade 1 to 4 ; the second cycle grades 5 and 6 ; the third cycle - from grade 7 to 9). This is then followed by secondary schooling from the tenth to the twelfth grade. to previous generations, Cigano children complete more years of education. However, after the fifth and sixth year of schooling, the number of Cigano children dropping out of formal education increases. Based on a literature review and a survey of policies, programmes and projects, and the analysis of interviews with individual and institutional stakeholders, the aim of this article is to present results of a research project that intends to identify key factors for the success and continuity of Cigano schooling paths.

\section{INTRODUCTION}

This article aims to present the impact of public policies on the schooling levels of Portuguese Ciganos, based on a wider research project entitled 'Key factors for the success and continuity of Cigano schooling paths: Individuals, families and public policy'. ${ }^{1}$ The majority of Portuguese Ciganos do not self-identify with the word Roma or Roms, but with the term Cigano, except some mediators, association leaders and people with average and higher education that know this designation, i.e., activists and Roma movement. For this reason we chose to use in this text the term Cigano, when we refer to the Portuguese Roma or Gypsies (Mendes, Magano \& Candeias, 2016). One of the project's main objectives is to analyse the impact of public policies on Portuguese Ciganos: men and women, individuals and families. The project was carried out in the metropolitan areas of Lisbon and Porto, in six territorial areas with a large presence of Ciganos and where there were projects aimed at them taking place. The methodology is qualitative and tries to combine several techniques: documental analysis, ethnographic observation in schools and in the neighbourhood in the two metropolitan areas of Porto and Lisbon, interviews and focus groups that capture multiple in-depth sources of information about the experiences and life paths in respect of the impact of social and policy measures. The innovative nature of the project lies in its focus on the interaction between social policies, education and identity reconfigurations with the intersection of multiple scales (neighbourhood, county, metropolitan area, national), as well as various techniques (data collection and analysis) and information sources.

The Social Integration Income (SII) is a case in point, and it seems important to scrutinize its effect in the gradual increase in the number of Cigano pupils enrolled in the third cycle ( 9 years) ${ }^{2}$ and at other levels of compulsory education. SII also has an important impact on the development of longer trajectories of schooling and on the increase of qualification pathways of the adult population. Hence, one of the hypotheses of the present study is: the existence of the SII's financial provision alongside a plan for social inclusion might affect the commitment of Cigano adults who have dropped out of education to return to school. This hypothesis calls for a careful analysis of education outcomes, especially since compulsory education has been extended to twelve years. It is therefore important to discover whether the increased schooling has granted access to more qualified positions in the labour market. Another related issue concerns the outcomes of the prolonged education of women: namely, how schooling affects their attitudes towards education as well as their position within the community, the family group and in relation to their children. Therefore, and in order to investigate the main hypothesis, we used such qualitative methods as ethnographic analysis, interviews and focus groups involving men, women, youths and other family members as well as social integration technicians, teachers, Cigano mediators and other professionals working in the area of social-educational 
integration. The present study is based on the assumption there might be a positive relationship between better educated Cigano adults and the number of Cigano youths enrolled in school. Hence, a range of protocols will be integrated, particularly those concerned with the implementation of SIII and other innovative programmes, like Choices (Escolhas) (which promotes the social inclusion of children and youths at risk) and Cigano mediators. Nevertheless, Portuguese Ciganos continue to experience high levels of illiteracy and school dropout (Mendes et al. 2014), even though during the last decade, during the process of European Union (EU) enlargement, the Roma issue became central to European political debates. The inequalities faced by the Roma across Europe were no longer confined to a set of countries, exposing the weakness of a prosperous Europe that has been unable to reduce the asymmetries between Roma and non-Roma for centuries. Even today, as a recent World Bank (2014) report shows, the disparities between a Roma family and an average European family gets wider every day, with a great majority of the former at high risk of poverty. Roma communities are in a position of socioeconomic vulnerability (FRA, 2012) reflecting a complex set of interrelated factors. Roma are affected by a self-perpetuating cycle of unequal opportunities, ethnic discrimination and stifled aspirations. With the launch in 2011 of the European Roma Integration Strategies, new possibilities have arisen to improve the living conditions of Roma in Europe and also, with the launch of the National Strategy (2013), also in Portugal.

Based on a literature review, a document analysis of public policies, programmes and projects and on interviews with Ciganos and individual and institutional stakeholders, this article presents a comprehensive reflection on some public policies that have had impacts on Ciganos schooling and offer some insights into the views of both the Cigano community and institutions.

\section{PUBLIC POLICIES AND EDUCATIONAL CONTINUITY AND SUCCESS OF CIGANOS: A REVIEW OF THE LAST 40 YEARS}

There are no public policies or social and educational programmes in Portugal that target Ciganos alone. Despite that, since the restoration of democracy after 1974, Portugal has implemented a number of measures designed to improve the education level of all citizens. In the 1990s, acting through the Intercultural Secretariat (Secretariado Entreculturas), the education ministry sought to organize a database with annual surveys on the multicultural demography of public schools. This measure was not continued and the last available data dates from the 2003-04 academic year. Also in the 1990s, the education ministry developed the Intercultural Education Project, (Projeto de Educação Intercultural), which was designed to promote the creation of intercultural education modules and educational materials containing information about Cigano culture. Given that these measures ended earlier than expected, and that they were not mandatory, their impact remains unknown. In the area of education, one of the most important programmes is the Priority Intervention Education Area (TEIP Territórios Educativos de Intervenção Prioritária) which since 2012 has been in its third generation (TEIP3). This programme has now existed for several years at schools in socio-economically disadvantaged areas around the country. The last available programme report states that more than 10 per cent of pupils in TEIP schools were Ciganos and that approximately half of the families whose children attend these schools are in receipt of SII (Pinto et al. 2012: 14). 
3. The initiative New Opportunities was implemented in 2005 as a joint action of the Ministry of Labour and Social Solidarity and the Ministry of Education, having as its goal the diversification of educational and training paths, the strengthening of professional positions, and the promotion of a school courses and educational success. The New Opportunities program was replaced in 2014 by the Network of Centers for Qualification and Vocational Education.
Another initiative worth highlighting is the New Opportunities Programme $^{3}$ ((2005-09), which sought to enhance the qualifications of Portuguese adults and facilitate their reintegration into the education system by developing adult qualification programmes suited to the inclusion of disadvantaged social groups (Gomes 2013). We have no data on the results of this programme, but we do know several Ciganos took part. The mandatory nature of this type of vocational training for SII recipients means that by taking into account the proportion of Cigano SII recipients, we know that Cigano men and women benefited.

More recently, the Escolhas programme, which in 2015 was in its fifth generation, and which mainly targets children and youngsters from socioeconomically disadvantaged areas, had some impact on Cigano individuals and their families at the national level, as our results confirm. Briefly, this programme seeks to use educational, artistic, recreational and vocational training activities to encourage school attendance and increase awareness of the overall importance of education through an approach involving great proximity with the communities in the areas in which they are operating. The fourth-generation programme report confirms that 16 per cent of the young people involved were Ciganos, who were present in 69 projects, representing the mobilization of 1956 children and young people (Saint-Maurice et al. 2011). In the fifth generation, the number of projects working with Ciganos expanded to 85. By working in close proximity with Ciganos aged from 6-24, the Escolhas programme continues to play an important role in promoting the success and continuity of schooling paths for some young Ciganos, helping contribute to reducing social inequalities in education.

The Integrated Programme for Education and Training (Programa Integrado de Educação e Formação [PIEF]), which has recently been renamed the Programme for Support and Qualification of PIEF (Programa de Apoio e Qualificação da Medida PIEF) also contains examples of good practice, although it has been controversial in some situations that ended in accusations of discrimination and segregation. Apart from these situations, when developed together with families it is a measure that has enjoyed wide acceptance within the families. This measure currently seeks to address school failure and indiscipline while preventing school dropout, and is perceived as the last resort before the pupil is completely lost to education. PIEF classes take place in a more informal and familiar setting and there is greater freedom of curriculum choice with different learning objectives. But it is important to be careful in identifying it as a best practice, because the fieldwork shows that PIEF classes quickly become known as 'Cigano classes' and it requires a great deal of effort to keep its 'temporary' and 'transitory' status. On the other hand, the fact these classes often took place, particularly at the beginning, closer to the community, meant some families preferred having their children there instead of at the regular school, which runs contrary to the programme's aims. Nevertheless, it should be noted that this measure had undeniably positive results in the decision of Cigano girls to stay on at school.

In recent years, the number of distance learning Cigano pupils has grown in the Lisbon Metropolitan Area, mainly of Cigano girls who have completed the first and the second cycle of education and/or their families who are opting for distance education. The families we talked with justified their choice as a result of the itinerant nature of their professional activities (although most of them seldom leave the municipality), the lack of vacancies 
in their preferred school, the unsafe and insecure school environment, their children's preference for distance learning and, in the case of girls' parents, their obligation to protect their daughters before marriage. This latter reason proved the main justification for the parents of adolescent girls choosing distance learning.

In the 2014-15 academic year, the Escolhas programme, as part of a partnership with the General Directorate of Education and the Fonseca Benevides School, which manages distance education in Portugal, launched a distance education pilot project. Although it does not specifically target Cigano pupils its design took the characteristics of the Cigano population in disadvantaged areas into account. This project is taking place at the national level in selected Escolhas projects. In relation to the former distance learning, the innovation is that students will not attend school at home but rather at local Escolhas projects, where they will have an opportunity to meet other pupils (who are usually their neighbours and relatives) and are followed by project technicians. Some stakeholders expressed concerns about considering distance learning a good measure for promoting Cigano schooling, noting that it might exacerbate existing gender inequalities by not allowing girls to interact with other pupils in a real school environment. For them, this is a regression in terms of the work that has been developed with these families.

Despite the rise in the levels of education of the Portuguese population in general, inequalities exist between Ciganos and non-Ciganos in general and between Cigano men and women in particular (Mendes 2007; Magano 2010). It is an indicator of a structural character and, in the case of the education of Ciganos, reflects the accumulated deficit from previous generations (Almeida et al. 1993). The persistence of early school leaving, particularly from the sixth year of education (despite compulsory education being set at the ninth year since 1986 and the twelfth year since 2009), is a worrying indicator, as is the fact many reach the school age limit without completing compulsory education or acquiring the necessary skills.

The new political perspective with the implementation of National Strategy for the Integration of Cigano Communities is expected to bring important changes that might contribute to reduce the pressing inequalities between Ciganos and non-Ciganos.

\section{PERSISTENT INEQUALITIES}

The expansion of the process of Portuguese Cigano families settling down in one place since the 1980s has made access to schooling easier. This change is evident when comparing past and present generations, especially in terms of academic success and continuity of schooling. Few of the elder generation had the chance to go to school and many never managed to learn how to read and write. In contemporary Portuguese society, the increasing of educational levels is directly related to trajectories of social mobility (Almeida et al. 1993). Average levels of education among Portuguese Ciganos remains lower than the national average and is more circumscribed in their case. The rise in educational levels among Portuguese Ciganos has also proved slower in relation to the rest of the population, which means the asymmetries between Ciganos and non-Ciganos in terms of academic qualifications remain very marked. In fact, to a large extent the younger generations continue to reproduce the situations of inequality inherited from their parents. Considering that the level of education attained is first and foremost a structural indicator, 
4. In a study conducted in Bragança, Cigano pupils had high rates of academic failure ( 45 per cent) and high drop-out rates (15 per cent) (Nicolau 2010).

5. It should be noted that only one had no schooling (Magano 2010). in the case of Portuguese Ciganos it ends up 'reflecting' not only'the shortfall in schooling accumulated over the last few decades', but also, and seen from a broader point of view, our country's 'unequal development logics' (Almeida et al. 1993: 316).

Since the late 1990s, Ciganos have had access to several programmes and measures designed to promote vocational training and enhance the educational qualifications of the overall population, even though recent data shows that a large number of Ciganos were excluded from some of these programmes and measures for not having the minimum educational requirements (usually, complete basic education). Education is very important for the social and cultural rights of individuals (Velho 1999) and is a key dimension in social mobility. In the case of Portuguese Ciganos, studies have found that the levels of schooling among them are generally very low (Cortesão 1995; Mendes 2007; Nicolau 2010). In a study by Mendes (2007), out of a total of 40 interviewees, eleven had never been part of the education system and seven could neither read nor write. The majority of the other interviewees attended the first four years of primary school. The low level of education reached more worrying proportions among women, most of whom had not even attended the first cycle of basic education (four years). ${ }^{4}$ It should be noted that no woman in the study had been educated beyond the third cycle (nine years). For Ciganos, the virtue of the woman is a protected value (Mendes 1997; Casa-Nova 2009), and depends on the possibility of inbreeding, which in turn depends largely on the maintenance of ethnic identity. It is to defend family honour and maintain a good image of girls when they are requested in marriage. As for the men, three had gone beyond compulsory education, including two who had completed a higher education course. These tendencies can be vouched for by data obtained by Magano (2010), with integrated Ciganos in the labour market where all the men who had attended school, one had a bachelor's degree (licenciatura) and two held MAs. In the case of the women, schooling levels were quite a bit lower, ${ }^{5}$ although three had completed nine years of schooling education (third cycle) and one had a university degree. Having said this, it is important to note that the education levels of the female interviewees were higher than those generally recorded in reference studies of Portuguese Ciganos (Bastos et al. 2007; Santos et al. 2009).

\section{INSIGHTS INTO THE SUCCESS AND CONTINUITY OF PORTUGUESE CIGANOS SCHOOLING PATHS}

In order to learn more about the areas with large populations of Cigano families in the Lisbon and Porto metropolitan areas, we conducted a set of exploratory semi-structured interviews with individual and institutional stakeholders, i.e. project and programme technicians and coordinators, responsible institution and association leaders who worked in the areas with a high number of Cigano residents. We tried to choose areas that were representative of the different existing realities in both metropolitan areas. Due to the living conditions of Ciganos in Portugal, all the areas were more or less marked by socio-economic vulnerabilities (social housing neighbourhoods and a few slum-dwelling areas), where most of the families had low levels of income and education. Another important condition was the existence of an institution or project that targeted Cigano individuals and families.

The primary focus of the interviews concerned educational issues, although other topics were also discussed. A total of 36 interviews were 
conducted, eighteen in each metropolitan area, between November 2013 and March 2014. The people interviewed, some of them Ciganos, worked mainly for private charities for and local government, but also in schools, cooperatives, non-profit associations, in a non-governmental organization for development and in a university. The interviewees came from a wide professional background and most had a university degree in social sciences. One aspect to highlight is the social intervention diversity with Cigano families and individuals, wherein some were working with the same families for the last 30 years and some for fewer than two years.

In terms of overall achievements, the interviewees who followed the same families for three decades said the life conditions of Ciganos have improved considerably over that time, especially in terms of education, health and housing conditions. For instance, interviewees noted that Ciganos had access to the same health care services available to the overall population living in the area and highlighted some housing policies that had moved most Ciganos families from the slums into social housing. As we confirmed during fieldwork, 10-30 years ago practically all Cigano families with which the people contacted worked lived in slums, and the majority were resettled under the Special Rehousing Programme (PER - Programa Especial de Realojamento) in blocks of flats built or adapted for this purpose. Of the very few situations where Cigano families were still living in slums, the interviewees noted that some of them had been waiting more than a decade for the promised resettlement. This was true for families from Paredes and Almada, in the Porto and Lisbon metropolitan areas, respectively.

In terms of access to education and educational performance, the interviewees agreed important goals had been achieved, such as the completion of the first four years of compulsory education, the implementation of the guaranteed minimum income in 1997, which was replaced by SII in 2003. SIIRSI was highlighted as the public policy that had most impact on the integration of Cigano children and youngsters into the education system, especially during pre-school and the first four years of primary school. The fact this measure involves the receipt of an income led some interviewees to overstress this aspect rather than a greater valuing of school and education within Cigano communities. On the other hand, some interviewees said significant changes can be observed. As one social action technician from Porto Metropolitan Area said:

[e]specially in terms of schools, it was very important. At this time, all Cigano children are attending pre-school [...] I have no drop-out in the first cycle. Seventeen years ago when I took them it was like 'Go to school?', 'I went to school once' and 'I've been there a year' and now they enrol themselves. Of course, it still works as a bargaining chip, I will not say it's not true. Many of them do things because otherwise the income is suspended, but I am pleased to see that incomes have been terminated and people are still in school.

(Social action technician, 40-44 years, Porto Metropolitan Area)

There was a consensus that Cigano children and youngsters remain in school longer and complete more years in the education system than their parents and grandparents, who were frequently illiterate or whose literacy and numeracy skills were insufficient for managing daily life and obtaining a profession requiring those skills. As reference studies and reports also indicate, among 
other factors this change was consolidated with the implementation of SII (ERRC/NÚMENA 2007; Magano 2010), which had the immediate effect of integrating a significant number of Cigano children in day care and preschool, something that was very unusual in the 1980s and 1990s (Mendes 1997, 2007).

In terms of day care and pre-school attendance, some interviewees noted there was still some resistance in using these facilities, particularly for infants and toddlers, but the majority agreed that today Cigano families are using these services more compared to a few decades ago, especially when the tuition is free or subsidized. The absence of official data makes it very difficult to objectively measure this social change, but we do know that a large number of Cigano children are now attending pre-school education, as was observed during fieldwork recently carried out in both metropolitan areas.

However, for the large majority of those interviewed, school success and the extension of schooling paths continue to fall short and progress is generally not evaluated as satisfactory by the interviewees. It was stated there was a marked tendency for the depreciation of long education paths by Cigano families as a consequence of cultural, social, economic and professional factors. According to them, Cigano families put great value in learning how to read, write and in performing calculations, which were the key skills for achieving the first cycle of basic education. From this level, the remaining content was not valued and the schooling paths begin to be marked by high drop-out rates and more demotivation. As one coordinator of a social institution, said:

[t]he school has been a struggle. We think so, we are almost sure, they still don't see the school as a priority and so [...] The school failure is tremendous. They miss school a lot and at this stage, when they pass from the fourth to the fifth year - which is the transition from first to the second cycle - is a problem. It's a problem! We don't have in so many years of work even one child who managed to make ninth grade. Everybody is in the fifth, sixth year. They cannot, it's not possible. We also feel that they no longer come well prepared from the first cycle.

(Coordinator of a social institution, 50-54 years,

Lisbon Metropolitan Area)

Indeed, all interviewees mentioned the difficulties faced during the transition from the first to the second cycle of education, which often represented a move to a larger school, sometimes geographically distant, an increased workload and a growing level of demand, having to deal on a day-today basis with several teachers and different people (other pupils, teachers and school staff), and stressed the discipline problems that have arisen in this transition. Besides this, other cultural aspects, as interviewees usually called them, were noted, such as the rather low priority of schooling with regard to other aspects of their lives, i.e. the 'Cigano way of life' at these ages (e.g. early marriage, family obligations, work for family trade); social pressure due to the fact there were few who had long school paths; the widespread devaluation of formal education; school failure; the absence of adequate support from families; and, finally, difficulty in meeting schedules and complying with the rules and regulations of formal education. Nevertheless, some important exceptions were noted, including those related to the life experiences of Ciganos interviewed: 
(I)

Our parents, in principle, do not value [...] school. We place greater value on fairs, markets, businesses and that kind of thing. Of course, it does not have prospects for the future because school is the future. Without knowing a bit of schooling we don't know how to learn anything - even how to get a driving licence.

(Sociocultural mediator, Lisbon Metropolitan Area)

(II)

The most successful pupils are those whose parents bother to take them to school. They meet schedules, they come here to make sure they are doing their homework; they do not let them miss school for everything and for nothing. They see school as a future for them. Although with most parents this still does not happen.

(Project coordinator, 35-39 years, Porto Metropolitan Area)

(III)

For them, school is not important. Ciganos live in the family, and (what matters) are the family problems [...] The child says, 'Oh! mother. Today I don't want to go to school', 'So don't go' is the response [...] to them the school is still a world apart [...] There are some who now see school in a different way, but it is very, very rare [...] if you ask a Cigano what he thinks the future for his son is, what he wants for his son, he might say 'I want to have a football player' [...] but it's all [...] because what they really want basically is to be a good Cigano, and to be a good Cigano is to follow the Cigano way of life.

(Coordinator of several social institutions, 50-54 years,

Lisbon Metropolitan Area)

Interviews with stakeholders showed the existence of a transversal idea that Ciganos did not value school as they should, which is also evident when interviewees talked about cases that go against this trend, which were perceived as being exceptional. The over-representation of Ciganos as an example of school failure seems to assume an important role in the processes of stereotyping, in which Ciganos are often targeted. In the same way, there was a great appreciation of the participation of Cigano pupils and also their families in school recreational activities. This corroborates the views of other interviewees that school is perceived to be an important socialization space for Ciganos of all ages.

In both metropolitan areas, and in terms of the completion of compulsory schooling, according to those interviewed, the majority of youngsters both boys and girls - they work with still do not complete basic education (third cycle of education), with higher drop-out rates between the fifth and the seventh year of education (ages 10-15). Interviewees said Ciganos reached fifth year of education without the necessary skills to succeed. In general, Cigano pupils only complete the first, and sometimes the second cycle; however, it is very rare for a Cigano to go on to secondary education. Moreover, none of the interviewees could name a Cigano in higher education, although two cases were mentioned - two male students who were expected to reach higher education. Additionally, it was noted that Ciganos were integrated in regular classes only when there was an individual history of repetitions or deductions were they were included in other curricula, such as PIEF classes, alternative curriculum courses, vocational 
courses or educational and training courses. It is also important to note that some interviewees highlighted changes in mentality in respect of the attendance of girls at school, particularly within families in which the father is not Cigano.

In the 72 interviews with Ciganos in the metropolitan areas and in the field work carried out in neighborhoods and schools, there have been significant changes in recent decades in relation to Ciganos - particularly evident in relation to women. Today, more parents take their children to school when they are called and even try to monitor their children's progress. They demonstrate a good appreciation of the school, which is in contrast to what happened in the past (in the case of parents who attended school):

We were going alone to school; there was no-one monitoring, such as attending school meetings; it was different. I think now things have changed.

(Woman, 31, First cycle-4 years of schooling education)

Also, times have changed now, right? We also had another monitoring [...] in the time of our parents, right? If we were at school then, our children will do better now!

(Woman, 38, First cycle-4 years of schooling education)

I used to cry. I wanted to go to school, but at that time it was the opposite! Children now do not want to go to school. It is an obligation! At that time, we wanted to go to school and our parents would not let us [...] And at school others made fun of us too. Even teachers [...] because we were Ciganos they put us apart.

(Woman, 45, three years of schooling education)

They aim to ensure their children have a different future, especially in terms of career choices and in seeking to ensure economic stability and social mobility. None of the people interviewed who remained in school longer (attendance at secondary school and university) attended only regular schools.

\section{SCHOOL PROGRAMMES AND PROJECTS TO HIGHLIGHT: TWO EXAMPLES}

While studies indicate the level of education of Portuguese Ciganos is lower than the rest of the population (Magano 2010; Nicolau 2010; Mendes 2007), this is not unique to Portugal (Levinson 2015; EU Agency for Fundamental Rights [FRA] 2012; ERRC/NÚMENA 2007).

Specifically, the 8,324 Portuguese Cigano children enrolled in school in the 2003-04 academic year, 86.7 per cent were in the first cycle. In secondary education (including technological courses) there were only a residual number of Cigano pupils (Comissão Parlamentar de Ética, Sociedade e Cultura [CPESC] 2008).

The interviewees who worked with populations in socio-economically disadvantaged areas may lead to the reproduction of stereotypes. As the interviewees frequently said, school absenteeism and school failure is also common in other population groups living in those areas. However, as a TEIP coordinator in the Lisbon Metropolitan Area explained, the presence of Cigano 
pupils in a school still requires a continuous and close intervention with the pupils and their families as a whole, and certainly more than with the other groups, because, as the TEIP coordinator notes, some of the situations facing Cigano pupils are shared:

We have several pupils from various countries, but those students who find it harder to accept the rules of the school as a whole are the Ciganos. Others also have pupil A, pupil B, pupil C, who also do not accept the rules and have behavioural problems, but collectively, is more a problem among the Ciganos.

(TEIP coordinator, 40-44 years, Lisbon Metropolitan Area)

For the two heads of TEIP schools who were interviewed, one from each metropolitan area, being part of this programme allowed their schools to better adapt to the needs of their pupils, particularly Ciganos pupils - for example, by allowing them to hire a sociocultural mediator, a Cigano woman in the case of Lisbon, and a Cigano man in Porto. In the case of the Lisbon TEIP school, for the first time a male Cigano managed to complete secondary education and hoped to enrol in university. In the Porto TEIP school, it became possible to enrol in the school all the Cigano children from a nearby slum in which they live in very precarious conditions. This fact, according to the Porto TEIP School head, is one of the main obstacles to integrating these students, which has a detrimental effect on their performance at school.

One final aspect to highlight concerns the relationships between Cigano pupils and their families, schools and teachers. As both heads noted, it is not always easy to manage the way teachers perceive and relate to Cigano students, particularly new teachers to the schools who frequently carry the prejudices of society into the classroom. It is therefore part of the heads' duties to change the perceptions and attitudes of teachers and to raise awareness of the particularities of this population. As the head of the Porto TEIP school explained:

[n]ew teachers who come here have not yet appropriated the sensitivity you must have to accept the difference. I have many colleagues who came here to say they cannot stand the smell of the students at school. This is a problem [...] of accepting Cigano students. They think school is for everyone, but it is 'annoying' having them all here. It is for everyone, but with all...

(Director of TEIP schools, 60-64, Porto Metropolitan Area)

A similar aspect was reinforced by the coordinator of two PIEF classes in Lisbon where several Cigano pupils are enrolled. PIEF, which has become a measure against early school drop-out and for promoting the inclusion and citizenship of youngsters, is now 'unmanageable', particularly because it can no longer select the human resources (including teachers) who work there. As the coordinator noted, this is due to the recent political changes taking place in the school system. To make matters worse, selected teachers are those who are in the most precarious professional situation. As a result, teachers are not generally motivated to work in the PIEF, or do not have a profile that is best suited for working with young people with those characteristics.

At the time, it was implemented, those who were in PIEFs were handpicked, so to speak. The teachers invited wanted to do this kind of work 
and they worked full-time in the PIEF. This allowed the teams to be more cohesive and to work better. Right now, due to all the impositions of the system, which are all determined by economics, people come here because they have not been assigned a schedule (school classes) or because their schedule is not complete. The person does not come by choice.

(PIEF coordinator, 35-39 years, Lisbon Metropolitan Area)

In Lisbon, two PIEF classes were identified as being 'good practices' by bringing young girls who had dropped out of school back into the education system: one example in Amadora and the other in Lisbon. The Amadora girls were aged between 14 and 16, and some were already married (Cigano marriage). Some of these young women were attending classes with their Cigano husbands; however, none of the girls were yet a mother.

The interviewees agreed there was a more severe social control towards girls attending school than towards boys, particularly after a certain age, which varied considerably between territories in both metropolitan areas. Despite the differences, it was noted that social control towards girls was directly related to the onset of puberty and with the marriage arrangements between families. In the opinion of the people interviewed, it is very difficult to keep girls who are engaged to be married in school. Not wanting to fall into generalizations, most interviewees said the age of 15 was considered a'good'age for girls to be married, with the engagement arrangements taking place a year before. However, as our fieldwork data also notes, this is not mandatory, with some families marrying off their daughters at the age of 13 (although cases were recorded, few families desired very early marriage) and in others only when they are 18 or even older. For boys, this seems to be more flexible; however, interviewees noted that after they reach the age of 18, Cigano boys begin being pressurized into matrimony and many get married before reaching this age. The following statements reflect the overall views of the interviewees in relation to these issues:

(I)

Girls, boys reach marriageable age, reach the age to turn to domestic work and then they leave school [...] For example, Cigano girls that are in the school, we can't force family members to encourage them to stay on because we can't go against their system and culture [...] so she will start missing a few days. We have spoken with the mother and with her in order to show her the benefits of staying on. But then people talk about all the other stuff. 'She is already getting tall', 'she is showing signs that she is becoming a woman',' possibly she is starting to think about getting married'.

(Project technician, 30-34 years, Lisbon Metropolitan Area)

(II)

It is still a major obstacle to make Cigano communities realise girls who continue studying do not stop being Cigano. Rather, at this point, in some communities what is happening is that girls are taken out of school while the boys continue their studies [...] And often these boys [...] do not want to marry girls who only studied until the fourth year, fifth or sixth year. This is also what we have to make parents realise.

(NGO technician, 35-39 years, Porto Metropolitan Area)

Gender inequality is also reproduced, mainly as a result of the early drop-out of Cigano girls, particularly between the ages of 11 and 14. The majority of 
Cigano boys stay on until they are aged between 16 and 18 (Mendes 2012). As a result, the compulsory education of twelve years is far from being achieved, especially among Cigano women. Notwithstanding the positive effects of measures such as SII, the number of Ciganos staying on in the school system is still limited and incomplete.

To conclude, for individual and institutional stakeholders, Cigano girls systematically dropout of the school system before boys and the continuity of schooling paths of Cigano boys is more dependent on their own will than is the case with the girls. Remarkably, the empirical evidence shows this fact does not result in the success and continuity of the schooling paths of boys (Mendes 2007; Magano 2010). On the other hand, several interviewees noted the fact that the schooling paths of Cigano girls were considered successful until they reached puberty, with some saying many girls were very motivated and enjoyed the school/classroom environment.

\section{DRAWING CONCLUSIONS: PUBLIC POLICIES FOR SOCIAL CHANGE?}

Today's Portuguese Ciganos are the most qualified generation ever. However, they remain the least educated in Portuguese society and do not yet complete compulsory education. The increase in levels of education is not reflected in the numbers of Ciganos who have an established professional occupation with an income that meets their basic needs. According to the people interviewed, almost all the Cigano households and individuals they know are unemployed and/or beneficiary of non-contributory social welfare benefits, most frequently SII. Despite that, as some interviewees noted and our fieldwork data confirms, many Ciganos remain involved in professional activities that are often linked, by others and Ciganos themselves, to a 'Cigano way of life', such as market fairs, street vending and more recently online trading and other informal occupations, even although the income they receive is not enough to cover their needs. Many others may also have occasional employment that is not declared due to the way social welfare benefits are paid. It should be noted that compulsory education has brought about profound change to the everyday life of Cigano families, as children who often accompanied their families to fairs are now at school and other institutions. This has brought greater freedom to Cigano parents and allowed them to look for opportunities in other activities.

Nevertheless, Cigano values in respect of employment are very negative, the result of a lack of opportunities in the labour market for paid employment, as well as their low academic and vocational qualifications. This creates a vicious circle in which those outside the labour market give up looking for employment because they think they know in advance that they will not get a job and will face a set of barriers that are difficult to overcome.

Surprising evidence emerges from a comparison with previous studies (Mendes 1997) which shows that Cigano families and individuals currently seem to live a double tendency: on the one hand, there is a reduction in traditional occupations; on the other, despite their increased qualifications, the number of Ciganos in the labour market, looking for paid employment, remains insignificant. Moreover, according to the interviewees and recent literature (Mendes et al. 2014; Castro 2010; CPESC 2008), the majority of Cigano households are dependent on social benefits, especially RSI.

As stated above, with the consolidation of the welfare state, in common with all of Portuguese society, Portuguese Ciganos experienced a significant 
improvement in their living conditions: this is also the view of the individual and institutional stakeholders interviewed, especially those who have accompanied the same families since 1974. The situation is the same in both metropolitan areas. The major identified improvements were mainly related to education, health and housing conditions, although we found a certain ambiguity in terms of the evaluation of the Ciganos' current situation in respect of employment.

By cross referring the sides of this analysis (literature review, the revision of public policies, programmes and projects and the analysis of interviews to stakeholders), it is clear that the consolidation of the welfare state in Portugal was fundamental for the overall improvement of the living conditions of Portuguese Ciganos. Considering the case of education as an example, even though there is still a long way to go, important steps have been taken. However, from the analysis of the opinions of interviewees it is also clear a mandatory rule requiring Cigano children to attend school does not by itself promote the expected long-term results. And this is not to mention the fact it was agreed that on the ground these rules were somehow 'easily' ignored after the first or second cycle of education. This means that the universalism of Portugal's social policies (which is designed to ensure equal dignity for all citizens) has not had the desired effect in terms of reducing levels of poverty, exclusion, discrimination and racism among and against Ciganos.

The educational level of Ciganos reflects an accumulated deficit from previous generations, while rising levels of qualifications is connected to the trajectories of social mobility in Portuguese society. Taking the situation of Portuguese Ciganos into consideration, there are parallels with those experienced by Ciganos in other European countries (Levinson 2015; Bhopal and Myers 2008; Myers et al. 2010; Miskovic 2013) it seems that the current situation Portuguese (and European) Ciganos find themselves in derives from structural inequalities more than from a lack of skills or a 'one-sided mismatch'.

\section{REFERENCES}

Almeida, J. F., Costa, A. F. and Machado, F. L. (1993), 'A recomposição sócioprofissional e os novos protagonismos' ('The socio-professional restoration and new protagonists'), in A. Reis (ed.), Portugal 20 Anos de Democracia (Portugal 20 Years of Democracy), Lisbon: Círculo de Leitores, pp. 307-30.

Alto-Alto-Comissário para a Imigração e Diálogo Intercultural (ACIDI) (2013), Estratégia Nacional para a Integração dos Ciganos (National Strategy for Ciganos Integration), Lisbon: Secretary of State of the Deputy Minister and Parliamentary Affairs/ACIDI.

Bastos, J. G. P., Correia, A. C. and Rodrigues, E. (2007), Sintrenses Ciganos: Uma Abordagem Estrutural-Dinâmica (Sintrenses Ciganos: A Structural-Dynamic Approach), Sintra: Câmara Municipal de Sintra.

Bhopal, K. and Myers, M. (2008), Insiders, Outsiders and Others: Gypsies and Identity, Hatfield: University of Hertfordshire Press.

Casa-Nova, M. J. (2009), Etnografia e Produção do Conhecimento: Reflexões Críticas a Partir de uma Investigação com Ciganos Portugueses (Ethnography and Production of Knowledge: Critical Reflections from an Investigation with Portuguese Roma), Lisbon: Alto Comissariado para a Imigração e Diálogo Intercultural. 
Castro, A. (2010), 'Ciganos e desigualdades sociais: Contributos para a inflexão de políticas públicas de cariz universalista' ('Gypsies and social inequalities: Contributions to the tipping policies of universal nature'), Forum Sociológico, 20, pp. 11-19.

Comissão Parlamentar de Ética, Sociedade e Cultura (CPESC) (2008), Relatório das Audições Efectuadas sobre Portugueses Ciganos no Âmbito do Ano Europeu para o Diálogo Intercultural (Report of the Hearings held on Portuguese Roma in the European Year for Intercultural Dialogue), report of the Subcomissão para a Igualdade de Oportunidades e Família, Lisbon: Assembleia da República, http://www.cmamadora.pt/images/artigos/extra/projetoscofinanciados/mediadoresmunicipais/pdf/mediadoresmunicipais_relatorio_ audicoes_ptciganos.pdf. Accessed 29 March 2017.

Cortesão, L. (1995), 'Reflexões críticas sobre a educação de crianças ciganas' ('Critical reflections on the education of Gypsy children'), in L. Cortesão and F. Pinto (eds), O Povo Cigano: Cidadãos na Sombra - Processos Explícitos e Ocultos de Exclusão (The Gypsy People: Citizens in the Shadows - Hidden and Explicit Processes of Exclusion), Porto: Afrontamento, pp. 27-36.

ERRC/NÚMENA (2007), Os Serviços Sociais ao Serviço da Inclusão Social: O Caso dos Ciganos (Social Services at the Service of Social Inclusion: The Case of the Roma), Lisbon: European Roma Rights Centre and NÚMENA.

European Agency for Fundamental Rights (FRA (2012), The Situation of Roma in 11 EU Member States: Survey Results at a Glance, Luxembourg: Publications Office of the European Union, Retrieved from fra.europa.eu/ sites/default/files/fra_uploads/2099-FRA-2012-Roma-at-a-glance_EN.pdf. Accessed 29 March 2017.

Gomes, M. do G. (2013), 'Políticas públicas de qualificação de adultos e comunidades ciganas: Movimentos inclusivos' ('Public policies qualification adults and Roma communities: Inclusive movements'), in M. Mendes and O. Magano (eds), Ciganos Portugueses: Olhares Plurais e Novos Desafios numa Sociedade em Transição (Portuguese Gypsies: Plural Perspectives and New Challenges in a Society in Transition), Lisbon: Mundos Sociais, pp. 81-91.

Levinson, M. P. (2015), “'What's the plan?” What plan? Changing aspirations among Gypsies youngsters, and implications for future cultural identities and group membership', British Journal of Sociology of Education, 36:8, pp. 1149-69.

Magano, O. (2010), 'Tracejar vidas normais: Estudo qualitativo sobre a integração social de indivíduos de origem cigana na sociedade portuguesa' (Tracing normal lives: A qualitative study on the social integration of Ciganos into Portuguese society'), Ph.D. thesis, Lisbon: Universidade Aberta.

Mendes, M. M. (1997), 'Etnicidade, grupos étnicos e relações multiculturais no âmbito de uma sociologia das relações étnicas e rácicas' ('Race, ethnic groups and multicultural relations within a sociology of ethnic and race relations'), MA thesis, Porto: Universidade do Porto.

— (2007), 'Representações face à discriminação: Ciganos e imigrantes russos e ucranianos na Área Metropolitana de Lisboa' ('Representations in the face of discrimination: Gypsies and Russians and Ukrainian immigrant in the Lisbon Metropolitan Area'), Ph.D. thesis, Lisbon: Universidade de Lisboa. - (2012), Identidades, Racismo e Discriminação: Ciganos da Área Metropolitana de Lisboa (Identities, Racism and Discrimination: Gypsies of the Lisbon Metropolitan Area), Lisbon: Caleidoscópio. 
Mendes, M. M., Magano, O. and Candeias, P. (2014), Estudo Nacional sobre as Comunidades Ciganas (National Study about Ciganos Communities), Lisbon: Alto Comissariado para as Migrações.

Mendes, M. M., Magano, O. and Candeias, P. (2016), 'Social and spatial continuities and differentiations among Portuguese Ciganos: Regional profiles', Studia UBB Sociologia, 61:LXI, pp. 5-36.

Miskovic, M. (ed.) (2013), Roma Education in Europe: Practices, Policies and Politics, London: Routledge.

Myers, M., McGhee, D. and Bhopal, K. (2010), 'At the crossroads: Gypsy and traveller parents' perceptions of education, protection and social change', Race Ethnicity and Education, 13:4, pp. 533-48.

Nicolau, L. (2010), 'Ciganos e não ciganos em Trás-os-Montes: Investigação de um impasse inter-étnico' ('Roma and non-Roma in Tras-os-Montes: Investigation of an inter-ethnic impasse'), Ph.D. thesis, Vila Real: Universidade de Trás-os-Montes e Alto Douro.

Pinto, C., Mendes, F., Oliveira, I., Soares, J., Parente, L., André, P. and Cunga, P. (2012), Relatório TEIP 2010-2011 (TEIP Report, 2010-2011), Lisbon: Ministério da Educação e Ciência, Direcção Geral da Educação.

Saint-Maurice, A., Costa, S., Pereira, V.P., Guerra, I. and Roldão, C. (eds) (2011), Programa Escolhas 2010-2011: $1^{\circ}$ Relatório de Progresso (Choices programme 2010-2011: 1st Progress Report), Lisbon: DINÂMIA/CET-IUL, ISCTE Instituto Universitáro de Lisboa.

Santos, T., Oliveira, C.R., Rosário, E., Kumar, R. and Brigadeiro, E. (2009), Research Survey on Migrant's Experiences of Racism and Xenophobia in Portugal, Porto Salvo: NÚMENA.

Velho, G. (1999), Projeto e Metamorfose: Antropologia das Sociedades Complexas (Project and Metamorphosis: Anthropology of Complex Societies), Rio de Janeiro: Zahar.

World Bank (2014), 'Roma', http://www.worldbank.org/en/region/eca/brief/ roma. Accessed 9 December 2015.

\section{SUGGESTED CITATION}

Mendes, M. M., Magano, O. and Costa, A. R. (2017), 'Public policies and social change: The case of the success and continuity of schooling paths of Ciganos', Portuguese Journal of Social Science 16:2, pp. 249-65, doi: 10.1386/ pjss.16.2.249_1

\section{CONTRIBUTOR DETAILS}

Maria Manuela Mendes is a professor at the University of Lisbon's Faculty of Architecture (FAUL). She has been a researcher at CIES, ISCTE - Instituto Universitário de Lisboa since 2008 and is a member at the Centre for Research Architecture, Urban Planning and Design (CIAUD- FAUL) and of the Institute of Sociology, Porto University (ISFLUP). Her research interests are ethnicity, immigration, city and diversity, social and spatial exclusion, local development, relocation and disqualified territories. Recent publications include Estudo Nacional sobre as Comunidades Ciganas (National Study about Ciganos Communities) (with Olga Magano and Pedro Candeias, 2014), 'Shaping ways of managing diversity in Portuguese schools from the student's perspective' (with Pedro Caetano, Revue Internationale de Sociologie, 24:2, 2014, pp. 325-44) and 'Immigrant perceptions of ethnic and racial discrimination: Patterns and 
singularities in a council of Lisbon Metropolitan Area' (with Pedro Candeias, International Review of Sociology, 23:2, 2013, pp. 400-19).

Contact: Faculdade de Arquitetura de Lisboa, Seção Ciências Sociais e do Território, R. Sá Nogueira, 1349-055 Lisboa, Portugal.

E-mail: manuela_mendes@iscte.pt

Olga Magano has been a professor at the Universidade Aberta since 2002, and a researcher at She has been a researcher at CIES, ISCTE - Instituto Universitário de Lisboa since 2015 and researcher at the Centre for Studies on Migrations and Intercultural Relations (CEMRI-UAb) since 1999. Her research interests are the integration and exclusion of Gypsies, identities, social change Social mobilization, Social trajectories and spatial and social exclusion. Recent publications include Tracing normal lives: between stigma and the will to be Cigano, Social Identities, 23:1, 44-55, 2017; 'Constrangimentos e oportunidades para a continuidade e sucesso das pessoas Ciganas' ('Key factors for continuity and the educational success of Ciganos in Portugal'), Configurações, 18, pp. 8-26, 2006 (with Maria Manuela Mendes); 'School pathways and economic practices of Portuguese Ciganos: some continuities and changes', Social Identities, 1-16 (with Maria Manuela Mendes), 'Social and spatial continuities and differentiations among portuguese ciganos: Regional profiles', Studia Ubb Sociologia, 61 (LXI), 1, 2016, (with Maria Manuela Mendes and Pedro Candeias).

Contact: Universidade Aberta - Delegação Regional do Porto, Rua do Amial, 752, 4200-055 Porto, Portugal.

E-mail: olga-magano@uab.pt

Ana Rita Costa has a MA in anthropology from the University of Coimbra. She is currently a doctoral candidate at ISCTE-IUL. She was a researcher in the CIES, ISCTE - Instituto Universitário de Lisboa project, 'Key factors for success and continuity of schooling paths of gypsies: Individuals, families and public policy'. Her research interests are Portuguese Roma (Ciganos) studies, media and technology, social networking and education.

Contact: Av. Forças Armadas, Edifício ISCTE-IUL, sala 2W2, 1649-026, Lisboa, Portugal.

E-mail: ana.rita.costa@iscte.pt

Maria Manuela Mendes, Olga Magano and Ana Rita Costa have asserted their right under the Copyright, Designs and Patents Act, 1988, to be identified as the authors of this work in the format that was submitted to Intellect Ltd. 


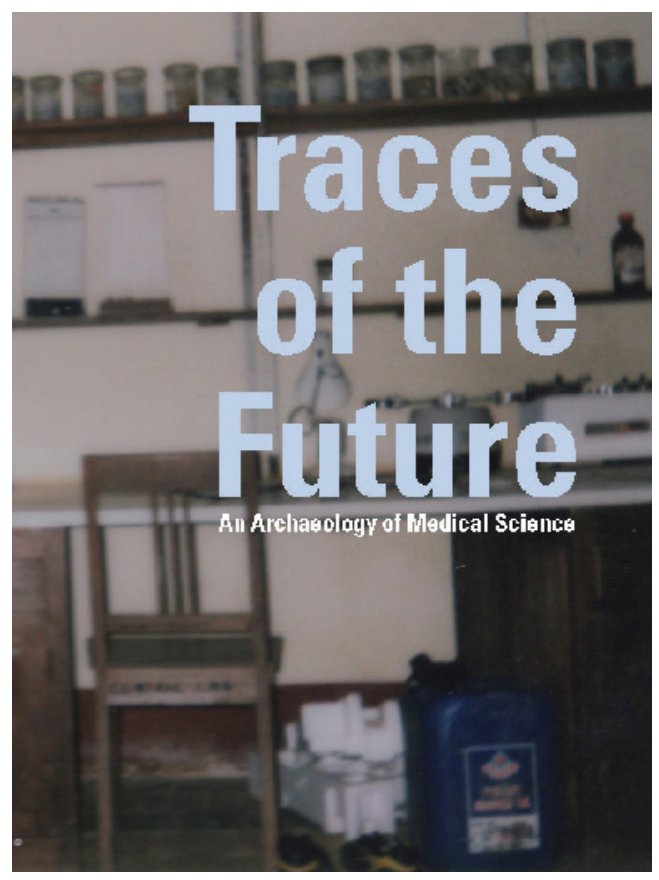

\section{Traces of the Future}

\section{An Archaeology of Medical Science in the Twenty-First Century Africa Edited by Paul Wenzel Geissler, Guillaume Lachenal, John Manton and Noémi Tousignant}

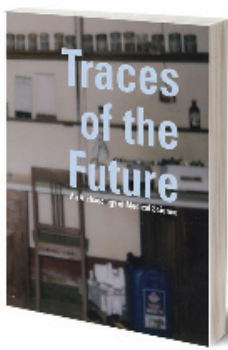

Price $£ 20, \$ 28.50$ ISBN 9781783207251 Paperback, 256 pages $230 \times 170 \mathrm{~mm}$ Published Fall 2016
This book presents a close look at the vestiges of twentieth-century medical work at five key sites in Africa: Senegal, Nigeria, Cameroon, Kenya and Tanzania. The contributors aim to understand the afterlife of scientific institutions and practices and the "aftertime" of scientific modernity and its attendant visions of progress and transformation. Straightforward scholarly work is juxtaposed here with altogether more experimental approaches to fieldwork and analysis, including interview fragments, brief, reflective essays and a rich photographic archive. The result is an unprecedented view of the lingering traces of medical science from Africa's past.

Paul Wenzel Geissler is a professor in the Department of Social Anthropology at the University of Oslo. Guillaume Lachenal is a lecturer at the Universite Paris Diderot, junior fellow of the Institut Universitaire de France. John Manton is associate professor of history at the London School of Hygiene and Tropical Medicine. Noémi Tousignant is affiliate member of the Department of Social Studies of Medicine at McGill and guest researcher in history at the Université de Montréal. 
Copyright of Portuguese Journal of Social Science is the property of Intellect Ltd. and its content may not be copied or emailed to multiple sites or posted to a listserv without the copyright holder's express written permission. However, users may print, download, or email articles for individual use. 